\title{
Drivers of social responsibility disclosure: the moderation of the president director's busyness and political connections
}

\author{
Ceicilia Bintang Hari Yudhanti
}

Akuntansi, Universitas Airlangga, Surabaya, Indonesia and

Akuntansi, Universitas Katolik Widya Mandala Surabaya, Surabaya, Indonesia, and

Bambang Tjahjadi

Akuntansi, Universitas Airlangga, Surabaya, Indonesia

\begin{abstract}
Purpose - This study aims to examine the effect of company size on social responsibility disclosure. In addition, this study examines the president director's busyness and political connections in moderating the association between company size and disclosure of corporate social responsibility.

Design/methodology/approach - The data used in this study were secondary data which included 1,165 observations (company-year). The analysis technique used was multiple regression method and the analysis was carried out by employing STATA software.

Findings - Researchers found that company size has a positive effect on social responsibility disclosure. The busyness of the president directors and companies connected to politics significantly weakens the association between company size and disclosure of social responsibility.

Research limitations/implications - This study uses only one measure of the driving force of social responsibility disclosure

Practical implications - This study contributes to the social responsibility literature by examining the effect of company size on social responsibility. Information on social responsibility disclosure has been carried out by companies in Indonesia; however, it is indicated that only large companies provide sufficient information on social responsibility.

Social implications - Stakeholders can find out information on social responsibility carried out by the company.

Originality/value - Companies with busy CEOs and politically connected firms weaken the association between company size and disclosure of social responsibility.

Keywords Social responsibility disclosure, Company size, President Director's busyness, Political connections Paper type Research paper
\end{abstract}

\section{Background}

Social responsibility is not a new practice for companies in Indonesia. Several companies have performed it, despite different systems in its implementation. Information regarding corporate social responsibility activities can be obtained via the companies' annual reports, as they disclose their social responsibility activities to their stakeholders. Social responsibility disclosure is defined as the sharing and dissemination of information by companies as part of

(C) Ceicilia Bintang Hari Yudhanti and Bambang Tjahjadi. Published by Emerald Publishing Limited. This article is published under the Creative Commons Attribution (CC BY 4.0) licence. Anyone may reproduce, distribute, translate and create derivative works of this article (for both commercial and non-commercial purposes), subject to full attribution to the original publication and authors. The full terms of this licence may be seen at http://creativecommons.org/licences/by/4.0/legalcode

Funding: This research has received funding from Universitas Katolik Widya Mandala Surabaya, Surabaya, Indonesia.

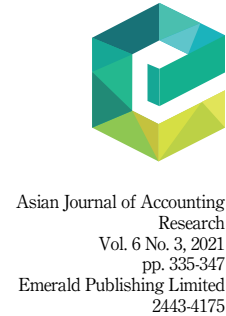

DOI 10.1108/AJAR-11-2020-0126 
AJAR 6,3

336 an annual report on matters related to operations, activities and application of certain programs that are considered to affect the public and different stakeholders (Chan et al.,2014). The implementation of social responsibility disclosure involves a process of communicating on how organization economic actions create the social and environmental impacts for certain interest groups in society and society at large (Gamerschlag et al., 2011).

Corporate social responsibility has attracted considerable attention from regulators, corporate executives, investors and various other stakeholders in recent decades. Companies are experiencing increased pressure to act according to social responsibility criteria and to disclose full information on this subject, in which information on environmental, social and community participation issues are of concern to a large number of stakeholders (Dawkins and Lewis, 2003). Following this direction, companies in Indonesia increasingly disclose corporate social responsibility information to the public. Conceptually, active involvement in social responsibility aims to get benefits, comply with the law, behave ethically and act as a good corporate citizen, to reflect the company's efforts to do what is right ethically which is of concern to stakeholders other than shareholders only (Wang et al., 2019).

Ali et al. (2017) argued in their literature review that company size is most often used to determine social responsibility disclosure in developing countries. The size of a firm reflects its resources and market power and what is at stake in economic and political conflicts (Olson, 1965). Compared to small and medium business, big companies are more likely to proactively seek socially responsible solutions which have international orientation (Knudsen, 2013; Bennie et al., 2007). Graafland and Smid (2012), for example, show that large Dutch companies tend to have a more positive perception on the impact of a good social responsibility reputation on long-term added value than small companies. The implementation of good social responsibility can positively affect customer loyalty and company image because customers prefer to make purchases from companies which care about environmental protection (Wei, 2020).

President directors with multiple positions are those who are granted as board members of directors for other companies (Schrand and Zechman, 2012). Jiraporn and Liu (2008), Gray and Nowland (2013) believe that the president directors with multiple executive positions have more experience to give better monitoring and advisory roles. However, the multiple positions held by directors have an impact on the possibility of fraudulent financial statements (Beasley, 1996). Furthermore, Fich and Shivdasani (2007) warned that having too many external directorships will impact the ineffectiveness of corporate governance, thus proving the rationality of the busyness hypothesis and therefore providing theoretical support for regulatory authorities to limit the number of directorships simultaneously.

Political connections include formal and informal relationships between local officials and top company managers (Bertrand et al., 2018; Faccio, 2010). Zhang et al. (2020) explain that a strong political relationship with the Chinese government will help realize two main internationalization interests: market exploration in developing countries and technology acquisition from developed countries. Voluntary disclosure can also be a political choice itself for certain political powers.

The substance and method of corporate communication, especially released by issuers, can become a political issue (Dicko et al., 2019). Cheng et al. (2015) pointed out that the level of environmental disclosure has increased from time to time. Chaney et al. (2011) argued that companies with strong political connections tend to be monitored by government and third parties. Tee (2020), explained further that political connections can be a source of severe agency problems for shareholders. As a result, they are reported to have lower earnings quality and unclear financial reporting

Disclosing information on social responsibility has been carried out by many Indonesian companies, but the amount of information submitted has not shown a significant increase. Therefore, this study is intended to examine how company size affects social responsibility 
disclosure. The researchers hypothesized that company size has a positive effect on social responsibility disclosure. In addition, this study is also aimed at examining whether this positive influence is weaker in companies which have busy president directors and companies which have strong political connections.

The present study has found that company size has an influence on social responsibility disclosure. Large companies are more closely monitored by the government and other stakeholders; therefore, they will disclose more social responsibility information. The literature of this study also finds consistent evidence that the positive influence is weaker in companies with busy CEOs. This indicates that the president directors who have multiple positions in other companies tend not to be able to manage the company better. In addition, the study finds that politically connected companies weaken the positive relationship between company size and social responsibility disclosure. This indicates that companies with political connections tend to provide less information about social responsibility.

This study contributes to the social responsibility literature by examining the effect of company size on social responsibility. Information on social responsibility disclosure has been carried out by companies in Indonesia; however, it is indicated that only large companies provide sufficient information on social responsibility. The findings show that large companies are better in conveying social responsibility information. Companies that have their president director serving on other directory boards as well as companies with political connections do not display stronger influence.

\section{Literature review and hypotheses \\ Theory of legitimacy}

Organizations seek to establish conformity between social values related to or implied by company activities and norms or code of conducts acceptable in the larger social system to which they are a part. Legitimacy, on the other hand, can be considered as adjusting the perception or assumption of an action taken by an entity in which the action is desired, appropriate or in line with a socially developed system of norms, values, beliefs and definitions (Suchman, 1995). Organizations intend to develop legitimacy for many reasons, and the propositions about the importance, difficulty and effectiveness of legitimacy efforts depend on the goals against which these efforts are measured. Two very important dimensions in this regard are (1) the difference between pursuing continuity and pursuing credibility and (2) the difference between seeking passive and active supports. Legitimacy theory suggests companies to ensure that their activities and performance be accepted by society. Companies, for example, use annual reports to give the positive impression of being environmentally responsible in order to be accepted by the society. The rationale for this theory is that an organization or company will continue doing these efforts if the society realizes that the organization operates for a value system that is in line with the community's own value system. Legitimacy theory suggests companies to ensure that their activities and performance be acceptable to society. Relying on the legitimacy theory, Buniamin (2010) claimed that companies with a higher level of environmental sensitivity report this information to minimize the potential political costs which might be imposed on the company in the future.

\section{Disclosure of corporate social responsibility}

Karim et al. (2015) argued that several companies see the importance of social responsibility and seek to have a positive impact on society. Market pressure through several networks such as conventional media and social media has an impact on companies' response to social responsibility challenges. Social responsibility activities require companies to have a positive

\section{Drivers of social responsibility disclosure}


impact on society through their business activities. McGuire et al. (1988) explained further that companies that carry out social responsibility will endure additional costs such as contributions to charity, promoting communication development plans, maintaining stability in economically distressed locations and establishing environmental protection procedures.

Companies must consider the benefits and costs of disclosing information on social responsibility. The literature on disclosure shows that the higher the level of disclosure, the lower the information asymmetry between managers and investors (Cho et al., 2013; Ferrero et al., 2015; Yoon and Lee, 2019). Furthermore, all messages that come from an organization, everything it produces and all the activities it involves will act to shape the perceptions of stakeholders (Melewar and Karaosmanoglu, 2006). This is in line with Robertson and Nicholson's (1996) claim that there has been a strong relationship between social responsibility and corporate communication.

\section{Company size}

Size is a variable that is often used to explain the extent to which a company discloses information. The literature on this study strongly argues that the level of social and environmental disclosure as a whole is positively related to company size (Monteiro and Guzman, 2010; Buniamin, 2010; Khan, 2010). Much evidence from previous research has supported a positive relationship between firm size and the extent of accounting disclosure. Large companies tend to expose more information because of several reasons:

(1) They get more public scrutiny than smaller companies; therefore, they are likely to disclose more information.

(2) Disclosing more information allows large companies to raise new funds at a lower cost.

(3) Large companies have sufficient resources to collect, analyze and present large amounts of data at minimal costs

\section{President director's busyness}

President directors hold one of the most important and influential roles in an organization. A director who holds multiple directorships is called a busy director. President directors who serve several positions on the board of directors of other companies have an incentive to develop a reputation as a good supervisor (Fama and Jensen, 1983). Hillman and Dalziel (2003) argued that board members with more relevant expertise, experience, knowledge and industry skills are able to make more informed decisions to help solve problems and improve company performance.

In the case of India, various directorships have developed mostly due to a lack of industry leadership with sufficient experience to serve on corporate boards (Sarkar and Sarkar, 2009). Ferris et al. (2003) insisted that the better the performance of the company where the director serves, the more likely he or she is to hold more board seats in the future. Directors associated with better performing companies have hold more director positions (Harford, 2003).

Elyasiani and Zhang (2015), however, believed that a busy managing director has positive and negative sides. On the plus side, busy directors do not only have potentially valuable knowledge and experience but also have a better position to acquire new information and enjoy reputational benefits. On the downside, a busy director may not have enough time and energy to monitor and advise company management to disclose more information.

\section{Political connections}

Fisman (2001) argued that politically connected companies are believed to have benefits for some companies. Hilman et al. (2004) listed four categories of causes for companies to engage 
in political activities. They cover corporate, industrial, issue and institutional factors. Companies carry out political activities to increase company values. This preference depends on certain company factors such as size, financial resources and dependence on government contracts. Foreign ownership or domestic ownership is also identified as important when a company carries out political activities. Companies with huge foreign ownership do less political activities.

Researchers in the area of political connections have suggested that political connections can improve accounting quality because they are subject to greater media scrutiny, in which they can provide stronger monitoring toward any manipulation. They may also have more readily access to subsidized finance or government contracts, which can blunt incentives to manage revenue for capital market and contractual purposes (Batta et al., 2015).

Belghitar et al. (2019) in their study revealed that companies which have politicians on their board of directors are highly leveraged, use more long-term debt, have large excess cash and are associated with low-quality financial reporting compared to their counterparts which do not have any political connections. Wang and Qian (2011) indicated that the positive relationship between corporate philanthropy and financial performance is stronger for companies without political connections than for those with political connections. Ang et al. (2013) underlined that political connections are likely to add value to both connected companies and/or managers. The value of high political connections is found in countries with higher levels of corruption.

\section{Hypothesis}

Large companies are assumed to have more activities which impact society (Andrew, 1989). In addition, various community groups pay close attention to large companies so that they will be under greater pressure to report their social activities to legitimize their business (Cowen et al., 1987). It is understandable that large companies make more disclosure because they tend to receive more attention from the general public and are therefore under greater pressure to show social responsibility (Kansal, 2014).

In the context of this study, researchers speculated that there should be positive influence of company size to the legitimacy of its business on corporate involvement in social responsibility disclosure. Then the first hypothesis is:

\section{H1. Larger companies tend to disclose more socially responsible information.}

Core et al. (1999) found that busy directors do not have enough time to carry out their duties. Jiraporn et al. (2009) showed that busier directors tend to miss more board meetings. The busyness hypothesis put forward by Ferris et al. (2003), who claimed that too many external directors' positions will cause excessive constraints on them and eliminate time and energy, make their supervisory role ineffective and thus weaken the efficiency of corporate governance. This indicates that a busy president director weakens the influence of company size and disclosure of social responsibility. Then the second hypothesis is:

H2. The positive influence on company size and social responsibility disclosure is weaker in companies which have a busy president director.

Cheng et al. (2015) displayed the positive results of research related to political connections and disclosure of environmental information. If political connections affect the company's environmental disclosure, it will be difficult to improve the quality of environmental disclosure and provide useful information for decision-makers. Deng et al. (2020) provided an empirical analysis showing that the political relationship between company top managers and mayors provides the institutional means through which the companies obtain strategic pollution release protection. Political ties also significantly increase the company's pollution discharge.

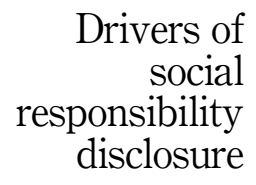

339 
AJAR 6,3

Zhang et al. (2020) found out that corporate political relations increase the likelihood for companies not to disclose any environmental information and decrease the likelihood for companies to refer to GRI's Sustainability Reporting Guidelines. Chaney et al. (2011) obtained research findings which indicated that connected companies disclosed lower quality of accountants' information due to a lack of need to respond to market pressures that demand increased information quality.

Therefore, researchers speculate that politically connected companies weaken the influence of company size and disclosure of social responsibility. Then the third hypothesis is:

H3. The positive influence between company size and social responsibility disclosure is weaker in companies with political connections.

\section{Research methods}

Data and samples

The initial sample included all companies listed on the Indonesia Stock Exchange for the 2013-2017 period. Sources of data in this study were taken from companies' annual reports, Indonesian Capital Market Data and OSIRIS database. These data sets were combined and sorted with the following sample selection criteria. First, all financial firms were excluded because of differences in their financial statements. Second, issuing companies in non-Rupiah currency were also excluded. Finally, any observations without complete data were excluded from the sample. After the sample selection criteria application, the final observation included 1,165 (firm-year) annual observations of the issuing companies.

\section{More explanation is presented below}

(1) In $2013(t=1)$, the number of the observed companies was $159(N=1)$ and the number of the unobserved companies was 162.

(2) In $2014(t=2)$, the number of the observed companies was $205(N=2)$ and the number of the unobserved companies was 116.

(3) In $2015(t=3)$, the number of the observed companies was $231(N=3)$ and the number of the unobserved companies was 90 .

(4) In $2016(t=4)$, the number of the observed companies was $272(N=4)$ and the number of the unobserved companies was 49.

(5) In $2017(t=5)$, the number of the observed companies was $298(N=5)$ and the number of the unobserved companies was 23 .

\section{Definition and measurement of operational variables}

The level of social responsibility disclosure is the dependent variable measured by using the Social Responsibility Disclosure Index (SRDI). The index was calculated with the following formula:

$$
\text { SRDI score }=\frac{K}{N}
$$

Note:

SRDI: social responsibility disclosure index

$K$ : the fulfilled index

$N$ : the expected total index 
This study used binary data to classify the presence or absence of social responsibility activities carried out by each company in each year based on the GRI-G4 category. The social responsibility score was measured by calculating the index of social responsibility disclosure obtained from the fulfilled index divided by the expected total index.

The size of the company tends to influence the amount of social responsibility disclosures needed to address the problems of different stakeholder groups. In this study, company size (Sz) as an independent variable was measured by:

$$
\mathrm{Sz}=\log \text { of assets }
$$

The moderating variable of the president director's busyness (DB) was measured by using label 1 to indicate that the main director has 2 or more other directorships and 0 for the main director who has fewer than 2 positions. The moderating variable size for political connections (PCs) employed the Faccio et al.'s (2006) measurement, in the form of a dummy variable in which companies with political connections were labeled 1 and 0 for others. Faccio defines a politically connected company as the one in which at least one major shareholders (whoever controls at least $10 \%$ of the vote) or one of the company leaders (CEO, director, deputy director, chairman or secretary) is a member of parliament, minister or has close ties with politicians or famous parties.

The control variables used in this study included leverage $(\mathrm{Lv})$ measured from the ratio of total debt divided by total assets at the end of the fiscal year, company's age (Ag) as measured by the number of years the company has operated and Sensitive Industry (SI) using Djajadikerta and Trireksani's (2012), and in the form of dummy variables, namely 1 for companies operating in sensitive industries and 0 for others.

\section{Methodology}

To test Hypothesis 1 in this study, the following regression model was implemented. Based on Hypothesis 1, the researcher expects the coefficient on $\mathrm{Sz}$ to be positive:

$$
\mathrm{SRDI}_{i t}=\beta_{1}+\beta_{2} \mathrm{Sz}_{i t}+\beta_{3} \mathrm{Lv}_{i t}+\beta_{4} \mathrm{SI}_{i t}+\beta_{5} \mathrm{Ag}_{i t}+\varepsilon
$$

Note:

SRDI: Social Responsibility Disclosure Index

Sz: Size

Lv: Leverage

Ag: Age

SI: Sensitive Industry

To test Hypothesis 2, the following model 2 was used. Researchers expected the coefficient on $\mathrm{Sz} * \mathrm{DB}$ to be positive:

$$
\mathrm{SRDI}_{i t}=\alpha+\beta_{1} \mathrm{Sz}_{i t} * \mathrm{DB}_{i t}+\beta_{2} \mathrm{Sz}_{i t}+\beta_{3} \mathrm{DB}_{i t}+\beta_{4} \mathrm{Lv}_{i t}+\beta_{5} \mathrm{SI}_{i t}+\beta_{6} \mathrm{Ag}_{i t}+\varepsilon
$$

Note:

DB: The president director's busyness

To test Hypothesis 3, the following model 3 was employed. Researchers expected the coefficient on $\mathrm{Sz} * \mathrm{PC}$ to be positive:

$$
\mathrm{SRDI}_{i t}=\alpha+\beta_{1} \mathrm{Sz}_{i t} * \mathrm{PC}_{i t}+\beta_{2} \mathrm{Sz}_{i t}+\beta_{3} \mathrm{PC}_{i t}+\beta_{4} \mathrm{Lv}_{i t}+\beta_{5} \mathrm{SI}_{i t}+\beta_{6} \mathrm{Ag}_{i t}+\varepsilon
$$




\begin{tabular}{l} 
AJAR \\
6,3 \\
$\mathbf{3 4 2}$ \\
\hline
\end{tabular}

Note:

PC: Political connections

\section{Results and discussion}

Descriptive statistics for all variables are presented in Table 1 . The mean SRDI value is 0.205 , with on average the company's disclosed social responsibility by $20.5 \%$. The mean value of $\mathrm{DB}$ is 0.511 , in which the average company that has a busy president director is $511 \%$. The mean value of $\mathrm{PC}$ is 0.41 , with on average the companies connected to politics are $41 \%$. The mean $\mathrm{Lv}$ value is 0.546 , in which on average the company has a leverage of $54.6 \%$. The mean value of $\mathrm{Sz}$ is 21.509, where the average company has assets of IDR. 2,587,796,000,000. The mean value of SI is 0.948 , in which the average company included in the sensitive industry category is 0.948 . The mean $\mathrm{Ag}$ is 31,794 , indicating the mean age of the company is 32 years.

Table 2 depicts Pearson correlation. The correlation between company size (Sz) and social responsibility disclosure (SRDI) in a predictable and significant direction. Other correlations between the independent variables are generally, low but do not pose a multicollinearity problem for our next analysis. The variance inflation factor (VIF) has an average of 1.06 and the highest is 1.15 .

Hypothesis testing was conducted using multiple regression analysis. The data analysis tool used in the study was STATA. Based on the Chow Test and Hausman Test, it can be concluded that the random effect model is the best model in estimating the regression model. The coefficient of determination (Adjusted $R 2$ ) shown by the adjusted $R 2$ model for regression 1, 2 and 3 was used to test the effect of company size on disclosure of corporate social responsibility.

Table 3 shows that the coefficient of determination (Adjusted $R 2$ ) for model 1 is 0.1071 ; the means that $10.72 \%$ of social responsibility disclosure is determined by the independent

\begin{tabular}{|c|c|c|c|c|}
\hline Variables & Mean & Median & Min & Max \\
\hline SRDI & 0.205 & 0.19 & 0.11 & 0.53 \\
\hline $\mathrm{Sz}$ & 21.509 & 21.493 & 15.75 & 26.413 \\
\hline DB & 0.511 & 1 & 0 & 1 \\
\hline $\mathrm{PC}$ & 0.41 & 0 & 0 & 1 \\
\hline $\mathrm{Lv}$ & 0.546 & 0.487 & 0 & 14.409 \\
\hline SI & 0.948 & 1 & 0 & 1 \\
\hline $\mathrm{Ag}$ & 31.794 & 32 & 1 & 105 \\
\hline
\end{tabular}

Table 1.
Descriptive statistics

Note(s): The table depicts descriptive statistics for all variables which include 1,165 observations

\begin{tabular}{|c|c|c|c|c|c|c|c|}
\hline \multicolumn{8}{|c|}{ Pearson correlation } \\
\hline Variables & SRDI & $\mathrm{Sz}$ & DB & $\mathrm{PC}$ & $\mathrm{Lv}$ & SI & $\mathrm{Ag}$ \\
\hline SRDI & 1.000 & & & & & & \\
\hline $\mathrm{Sz}$ & $0.217 * * *$ & 1.000 & & & & & \\
\hline DB & 0.036 & $0.167 * * *$ & 1.000 & & & & \\
\hline $\mathrm{PC}$ & $0.051 *$ & $0.272^{* * *}$ & 0.007 & 1.000 & & & \\
\hline $\mathrm{Lv}$ & -0.021 & $-0.128 * * *$ & -0.032 & -0.002 & 1.000 & & \\
\hline SI & $0.131^{* * * *}$ & -0.018 & $-0.049 *$ & $-0.082 * * *$ & 0.026 & 1.000 & \\
\hline $\mathrm{Ag}$ & 0.241 *** & $0.117^{* * * *}$ & -0.018 & $0.074^{* *}$ & 0.016 & $0.097 * * *$ & 1.000 \\
\hline \multicolumn{8}{|c|}{$\operatorname{Note}(\mathbf{s}): * * * p<0.01, * * p<0.05, * p<0.1$} \\
\hline
\end{tabular}

Table 2.

Pearson correlation

Pearson correlation 


\begin{tabular}{|c|c|c|c|c|}
\hline & $\begin{array}{l}(1) \\
\text { SRDI }\end{array}$ & $\begin{array}{l}(2) \\
\text { SRDI }\end{array}$ & $\begin{array}{l}(3) \\
\text { SRDI }\end{array}$ & $\begin{array}{r}\text { Drivers of } \\
\text { social }\end{array}$ \\
\hline $\begin{array}{l}\mathrm{Sz} \\
\mathrm{DB} \# \mathrm{Sz}\end{array}$ & $0.008 * * * *(0.0011)$ & $0.0101 * * *(0.0017)$ & $0.0107 * * * *(0.0014)$ & $\begin{array}{l}\text { disclosure } \\
\text { disclon }\end{array}$ \\
\hline $\begin{array}{l}\mathrm{PC} \# \mathrm{Sz} \\
\mathrm{P}\end{array}$ & & & $-0.0058 * *(0.0023)$ & \\
\hline DB & & $0.0911^{*}$ & & \\
\hline $\mathrm{PC}$ & & & $0.1239 * *$ & 343 \\
\hline $\begin{array}{l}\text { Lv } \\
\text { SI }\end{array}$ & $\begin{aligned}-0.0002(0.0018) \\
0.0352^{* * * *}(0.0034)\end{aligned}$ & $\begin{array}{l}0.0002(0.0018) \\
0.0354 * * *(0.0035)\end{array}$ & $\begin{array}{l}0.0001(0.0018) \\
0.0353 * * *(0.0034)\end{array}$ & \\
\hline $\mathrm{Ag}$ & $0.0009 * * *(0.0002)$ & $0.0009 * * *(0.0002)$ & $0.001^{* * * *}(0.0002)$ & \\
\hline _cons & $-0.0292(0.0245)$ & $-0.0759 * *(0.0368)$ & $-0.0874 * * * *(0.0313)$ & \\
\hline Observations & 1,165 & 1,165 & 1,165 & \\
\hline$R$-squared & 0.1071 & 0.1097 & 0.1116 & \\
\hline \multicolumn{4}{|c|}{$\begin{array}{l}\text { Note(s): Robust standard errors are in parentheses } \\
* * * * p<0.01, * * p<0.05, * p<0.1\end{array}$} & $\begin{array}{r}\text { Table } 3 . \\
\text { Regression test }\end{array}$ \\
\hline
\end{tabular}

variables used in this study. While the rest $(100-10.71 \%=89.29 \%)$ is determined by other causes outside of model 1. Model 2 shows that the coefficient of determination (Adjusted $R 2$ ) is 0.1097 , meaning $10.97 \%$ disclosure of responsibility social SI determined by the independent variables used in this study. While the rest $(100-10.97 \%=89.03 \%)$ is determined by reasons other than model 2. Model 3 shows that the coefficient of determination (Adjusted $R 2$ ) is 0.1081 ; this means $11.16 \%$ disclosure of social responsibility is determined by the independent variables used in this study. While the rest $(100-11.16 \%=88.84 \%)$ is determined by other causes outside of model 3 .

The results of testing model 1 show that it is possible to justify the hypothesis that company size affects social responsibility disclosure. Table 3 shows that company size and social responsibility disclosure are positively associated at the $1 \%$ level. These results indicate that larger firms express greater social responsibility compared to smaller firms. Therefore, $\mathrm{H} 1$ is statistically supported.

The results of model 2 test show that it is able to justify the hypothesis that the president's busyness weakens the influence of company size on social responsibility disclosure. Table 3 shows a negative coefficient at a significance level of $10 \%$. These results indicate that companies whose president directors have executive positions at other companies tend to disclose less social responsibility than those that do not have a president director with no concurrent positions. Therefore, $\mathrm{H} 2$ is statistically supported.

The results of testing model 3 show that it is able to justify the hypotheses that companies connected to politics weaken the effect of company size on social responsibility disclosure. Table 3 shows a negative coefficient and SI at a significance level of $10 \%$. These results indicate that companies connected politically tend to disclose less information about social responsibility and less transparency in conveying information on social responsibility to stakeholders. Therefore, H3 is statistically supported.

\section{Conclusion}

This study aims to investigate whether company size affects corporate social responsibility disclosure. This is currently an important problem in Indonesia because the researchers' observations in the company's annual report found that the company still do not provide sufficient information about social responsibility. The company still does not consider social responsibility practices as a guarantee for the company's brand and reputation. However, several companies already have social responsibility programs that are sustainable, and they always provide information to stakeholders. 
AJAR 6,3

\section{4}

The present research discovers that company size affects the disclosure of corporate social responsibility. This result indicates that companies with large assets tend to be more able to conduct and convey social responsibility information. Companies should be aware that disclosing sufficient information to the public, of course, requires a lot of money. Therefore, companies need to be supported with company's resources as reflected in the assets owned by the company.

The practice of social responsibility requires several stages starting from the planning stage to the delivery of information. This study proves that president directors who have directorial positions in other companies tend not to have the time and focus on managing the company. The busy president director who divides his/her time between several companies will affect the company's operations. In addition, a busy president director will run out of energy in managing and overseeing company activities.

Finally, the present research also finds that politically connected companies do not help strengthen company size and social responsibility disclosures. Politically connected companies tend to be less transparent in conveying information to the public, especially in the case that the information is submitted voluntarily.

This study has limitations. It uses size as the independent variable as measured by log assets. Company size and company performance can be measured in various ways. Further research can take other variables and the potential factors that affect the level of social responsibility disclosure. Moderation and mediation variables can be used to test the level of social responsibility disclosure.

\section{References}

Ali, W., Frynas, J.G. and Mahmood, Z. (2017), "Determinants of corporate social responsibility (CSR) disclosure in developed and developing countries: a literature review", Corporate Social Responsibility and Environmental Management, Vol. 24 No. 4, pp. 273-294.

Andrew, B.H., Gul, F.A., Guthrie, J.E. and Teoh, H.Y. (1989), "A note on corporate social disclosure practices in developing countries: the case of Malaysia and Singapore", The British Accounting Review, Vol. 21, pp. 371-376.

Ang, J.S., Ding, D.K. and Thong, T.Y. (2013), "Political connection and firm value", Asian Development Review, Vol. 30 No. 2, pp. 131-166.

Batta, G., Heredia, R.S. and Weidenmier, M. (2015), "Political connection and accounting quality under high expropriation risk”, European Accounting Review, Vol. 23 No. 4, pp. 485-517.

Beasley, M.S. (1996), "An empirical analysis of the relation between the board of director composition and financial statement fraud”, The Accounting Review, Vol. 71 No. 4, pp. 443-465.

Belghitar, Y., Clark, E. and Saeed, A. (2019), "Political connections and corporate financial decision making", Review of Quantitative Finance and Accounting, Vol. 53 No. 5, pp. 1099-1133.

Bennie, L., Bernhagen, P. and Mitchell, N.J. (2007), "The logic of transnational action: the good corporation and the global compact", Political Studies, Vol. 55, pp. 733-753.

Bertrand, M., Kramarz, F., Schoar, A. and Thesmar, D. (2018), "The cost of political connections", Review of Finance, Vol. 22 No. 3, pp. 849-876.

Buniamin, S. (2010), "The quantity and quality of environmental reporting in annual report of public listed companies in Malaysia”, Issues in Social and Environmental Accounting, Vol. 4 No. 2, pp. 115-135.

Chan, M.C., Watson, J. and Woodliff, D. (2014), "Corporate sustainable development: testing a new scale based on the mainland Chinese context", Journal of Business Ethics, Vol. 105 No. 4, pp. 519-533.

Chaney, P.K., Faccio, M. and Parsley, D. (2011), "The quality of accounting information in politically connected firms", Journal of Accounting and Economics, Vol. 51 Nos 1-2, pp. 1-19. 
Cheng, Z., Wang, F., Keung, C. and Bai, Y. (2015), "Will corporate political connection influence the environmental information disclosure level? Based on the panel data of a-shares from listed companies in Shanghai stock market”, Journal of Business Ethics, Vol. 143 No. 1, pp. 209-221.

Cho, B.B., Lee, D. and Park, Y. (2013), "Corporate social responsibility, corporate governance and earnings quality: evidence from Korea”, Corporate Governance: An International Review, Vol. 21 No. 5, pp. 447-467.

Core, J.E., Holthausen, R.W. and Larcker, D.F. (1999), "Corporate governance, chief executive officer compensation, and firm performance”, Journal of Financial Economics, Vol. 51, pp. 371-406.

Cowen, S., Ferreri, L.B. and Parker, L.D. (1987), "The impact of corporate characteristics on social responsibility disclosure: a typology and frequency-based analysis", Accounting, Organizations and Society, Vol. 12 No. 2, pp. 111-122.

Dawkins, J. and Lewis, S. (2003), "CSR in stakeholder expectations and implication for company strategy", Journal of Business Ethics, Vol. 44, pp. 185-193.

Deng, Y., Wu, Y. and Xu, H. (2020), "Political connections and firm pollution behaviour: an empirical study", Environmental and Resource Economics, Vol. 75 No. 4, pp. 867-898.

Dicko, S., Khemakhem, H. and Zogning, F. (2019), "Political connections and voluntary disclosure: the case of Canadian listed companies", Journal of Management and Governance, Vol. 24 No. 2, pp. 481-506.

Djajadikerta, H.G. and Trireksani, T. (2012), "Corporate social and environmental disclosure by Indonesian listed companies on their corporate web sites", Journal of Applied Accounting Research, Vol. 13 No. 1, pp. 21-36.

Elyasiani, E. and dan Zhang, L. (2015), "Bank holding company performance, risk, and 'busy' board of directors", Journal of Banking and Finance, Vol. 60, pp. 239-251.

Faccio, M. (2010), "Differences between politically connected and nonconnected firms: a cross-country analysis", Financial Management, Vol. 39 No. 3, pp. 905-928.

Faccio, M., Masulis, R.W. and McConnell, J.J. (2006), "Political connections and corporate bailouts", The Journal of Finance, Vol. 61 No. 6, pp. 2597-2635.

Fama, E.F. and Jensen, M.C. (1983), "Separation of ownership and control", The Journal of Law and Economics, Vol. 26 No. 2, pp. 301-325.

Ferrero, J., M., Sanchez, I.M.G. and Ballesteros, B.C. (2015), "Effect of financial reporting quality on sustainability information disclosure", Corporate Social Responsibility and Environmental Management, Vol. 22 No. 1, pp. 45-64.

Ferris, S.P., Jagannathan, M. and Pritchard, A.C. (2003), "Too busy to mind the business? Monitoring by directors with multiple board appointments", The Journal of Finance, Vol. 58 No. 3, pp. 1087-1111.

Fich, E.M. and Shivdasani, A. (2007), "Financial fraud, director reputation, and shareholder wealth", Journal of Finance and Economics, Vol. 86 No. 2, pp. 306-336.

Fisman, R. (2001), "Estimating the value of political connections", The American Economic Review, Vol. 91 No. 4, pp. 1095-1102.

Gamerschlag, R., Moller, K. and Verbeeten, F. (2011), "Determinants of voluntary CSR disclosure: empirical evidence from Germany”, Review of Managerial Science, Vol. 5 Nos 2-3, pp. 233-262.

Graafland, J. and Smid, H. (2012), "Drivers of corporate social responsibility", Sustainability Development Drivers, Edward Elgar Publishing, pp. 156-183.

Gray, S. and Nowland, J. (2013), "Is prior director experience valuable?", Accounting and Finance, Vol. 53 No. 3, pp. 643-666.

Harford, J. (2003), "Takeover bids and target directors' incentives: the impact of a bid on directors' wealth and board seats", Journal of Financial Economics, Vol. 69, pp. 51-83. 
Hillman, A.J. and Dalziel, T. (2003), "Boards of directors and firm performance: integrating agency and resource dependence perspectives", Academy of Management Review, Vol. 28 No. 3, pp. 383-396.

Hillman, A.J., Keim, G.D. and Schuler, D. (2004), "Corporate political activity: a review and research agenda”, Journal of Management, Vol. 30 No. 6, pp. 837-857.

Jiraporn, P., Davidson, W.N., DaDalt, P. and Ning, Y. (2009), "Too busy to show up? An analysis of directors' absences”, The Quarterly Review of Economics and Finance, Vol. 49 No. 3, pp. 1159-1171.

Jiraporn, P. and Liu, Y. (2008), "Capital structure, staggered boards, and firm value”, Financial Analysts Journal, Vol. 64 No. 1, pp. 49-60.

Kansal, M., Joshi, M. and Batra, G.S. (2014), "Determinants of corporate social responsibility disclosures: evidence from India”, Advances in Accounting, Vol. 30 No. 1, pp. 217-229.

Karim, K., Suh, S., Carter, C. and Zhang, M. (2015), "Corporate social responsibility: evidence from the United Kingdom”, Journal of International Business Research, Vol. 14 No. 1, pp. 85-100.

Khan, H. (2010), "The effect of corporate governance elements on corporate social responsibility (CSR) reporting: empirical evidence from private commercial banks of Bangladesh", International Journal of Law and Management, Vol. 52 No. 2, pp. 82-109.

Knudsen, J.S. (2013), "The growth of private regulation of labor standards in global supply chains: mission impossible for western small- and medium-sized firms?", Journal of Business Ethics, Vol. 117, pp. 387-398.

McGuire, J.B., Sundgren, A. and Schneeweis, T. (1988), "Corporate social responsibility and firm financial performance”, Academy of Management Journal, Vol. 31 No. 4, pp. 854-872.

Melewar, T.C. and Karaosmanoglu, E. (2006), "Seven dimension of corporate identity: a categorization from the practitioners' perspectives", European Journal of Marketing, Vol. 40, pp. 846-869.

Monteiro, S.M.S. and Guzman, B.A. (2010), "Determinants of environmental disclosure in the annual reports of large companies operating in Portugal", Corporate Social Responsibility and Environmental Management, Vol. 17 Nos 4, pp. 185-204.

Olson, M. (1965), The Logic of Collective Action: Public Goods and the Theory of Groups, Harvard University Press, Cambridge, Massachusetts.

Robertson, D.C. and Nicholson, N. (1996), "Expression of corporate social responsibility in U.K. firms", Journal of Business Ethics, Vol. 15 No. 10, pp. 1095-1106.

Sarkar, J. and Sarkar, S. (2009), "Multiple board appointments and firm performance in emerging economies: evidence from India", Pacific-Basin Finance Journal, Vol. 17 No. 2, pp. 271-293.

Schrand, C.M. and Zechman, S.L.C. (2012), "Executive overconfidence and the slippery slope to financial misreporting", Journal of Accounting and Economics, Vol. 53, pp. 311-329.

Suchman, M.C. (1995), "Managing legitimacy: strategic and institutional approaches", Managing legitimacy: strategic and institutional approaches, Academy of Management Review, Vol. 20 No. 3, pp. 571-610.

Tee, C.M. (2020), "Political connections and income smoothing: evidence of institutional investors' monitoring in Malaysia", Journal of Multinational Financial Management, Vol. 55 No. 3, pp. 1-18.

Wang, F., Xu, L., Guo, F. and Zhang, J. (2019), "Loan guarantees, corporate social responsibility disclosure and audit fees: evidence from China", Journal of Business Ethics, Vol. 166 No. 2, pp. 293-309.

Wang, H. and Qian, C. (2011), "Corporate philanthropy and corporate financial performance: the roles of stakeholder response and political access", Academy of Management Journal, Vol. 54 No. 6, pp. 1159-1181.

Wei, L. (2020), "Examining corporate communications of environmental responsibility on corporate websites: main themes, linguistic features, and text reuse", Journal of Promotion Management, Vol. 26 No. 7, pp. 1013-1037. 
Yoon, B. and Lee, J. (2019), "Corporate social responsibility and information asymmetry in the Korean market: implications of Chaebol affiliates", Journal of Asian Finance, Economic and Business, Vol. 6 No. 1, pp. 21-31.

Zhang, G., Zhang, Q. and Huang, D. (2020), "Impact of political connection strength on the internationalization outcome of Chinese firms: perspectives from market exploration and technology acquisition”, Sustainability, Vol. 12 No. 24, pp. 1-23.

Drivers of social responsibility disclosure

\section{Corresponding author}

Ceicilia Bintang Hari Yudhanti can be contacted at: bintang@ukwms.ac.id

For instructions on how to order reprints of this article, please visit our website:

www.emeraldgrouppublishing.com/licensing/reprints.htm

Or contact us for further details: permissions@emeraldinsight.com 